\title{
Neuropsychopharmacological Effects of Dacryodes edulis Pulp Oil in Unpredictable Chronic Mild Stress Model of Depression in Mice
} \author{
Moukassa $^{1,3}$ and Ange Antoine Abena ${ }^{1}$ \\ ${ }^{1}$ Faculty of Health Sciences, Marien NGOUABI University, BP 69 Brazzaville (Congo) \\ ${ }^{2}$ National Public Health Laboratory, Brazzaville (Congo) \\ ${ }^{3}$ Edith Lucie Bongo Ondimba General Hospital, Oyo, Brazzaville (Congo)
}

Landry Martial Miguel ${ }^{1 *}$, Nadège Okemy-Andissa ${ }^{2}$, Didier Gesril N'Jilo ${ }^{1}$, Etienne Mokondjimobe ${ }^{1,2}$, Donatien

Submission: September 01, 2019; Published: September 16, 2019

*Corresponding author: Landry Martial Miguel, Faculty of Health Sciences, Marien NGOUABI University, BP 69 Brazzaville (Congo)

Abstract

Goal: To investigate the effects of prolonged (30-day) fruit oil administration of Dacryodes edulis (G. Don) HJ Lam (HDE) on the symptoms of depression induced by unpredictable chronic middle stress in mice.

Methods: Depression was induced by daily exposure animals to a succession of stressors for 6 weeks. Coat state, latency and the duration of immobility in the forced swimming and tail suspension tests were then determined after treatment with $\mathrm{HDE}$ ( 5 and $10 \mathrm{ml} / \mathrm{kg}$ ) and fluoxetine $(2,5 \mathrm{mg} / \mathrm{kg})$ for 4 weeks.

Results: HDE, at doses of 5 and $10 \mathrm{ml} / \mathrm{kg}$, improves the score related to coat state, increases latency and decreases the duration of animal immobility in forced swimming and caudal suspension tests. These results are similar to those obtained with fluoxetine (FLU).

Conclusion: The results confirm the antidepressant effects of HDE on symptoms of depression, in an unpredictable chronic middle stress model, after prolonged administration in mice.

Keywords: Dacryodes edulis; Depression; Neuropsychopharmacological; UCMS

\section{Introduction}

Stress is a crucial determinant for maintenance of health and disease [1,2]. There are various neuropsychiatric problems such as anxiety, cognitive dysfunction, depression etc., are generally associated with stress [3]. Depression is a mental condition that is characterized by affective, physical, physiological and cognitive deterioration [4-6]. It affects about $20 \%$ of the world's population [7]. To date, drug therapies available include tricyclic antidepressants, selective serotonin reuptake inhibitors (SSRIs) or noradrenalin (ISRN), and several other antidepressants such as monoamine oxidase inhibitors - MAOIs [8]. However some of these drugs have many side effects such as fatigue, sedation, apathy, sleep disorders, making it necessary, the development of other drugs more effective and better tolerated. In the clinic, several scales are used to assess the intensity of stress or depression; Hamilton Depression Rating Scale (HDRS), Montgomery-Asberg Depression Rating Scale (MADRS) or Beck Depression Inventory (BDI). These tests are based on behaviors assessment related to the symptoms of depression. Stress has an important role in the development of human depression [9]. The socio-environmental chronic stressors influencing the development of depression and stress in animal models, have been used to explore the biochemical mechanisms of these disorders. These models reproduce the symptomatology of depression observed in men $[7,10]$. It has been established that prolonged exposure of an animal to a variety of stressors is associated with significant behavioral, physiological, endocrine and neurobiological changes. These changes are corrected by chronic antidepressant treatments $[11,12]$. 
Reactive oxygen species (ROS) may play a role in some neuropsychiatric disorders such as major depression. There is some evidence that the activation of immune-inflammatory process, increased monoamine catabolism, and abnormalities in lipids may cause overproduction of ROS, lipid peroxidation, and reduced antioxidant enzyme activities, and these processes may be related to pathophysiology of depression [13].

Dacryodes edulis (G. Don) HJ. Lam (Burseraceae), is a potent natural antioxidant and is currently receiving considerable attention in relation to neuropsychological disorders. Phytochemical studies have revealed the presence of various chemical compounds that would justify the medicinal indications of this plant. The fruits of $D$. edulis are rich in lipids, proteins, vitamins and antioxidants. Pharmacological studies have shown psychotropic properties of antidepressant and anxiolytic types [14,15].
In present study, we have evaluated the antidepressant-like effect of long term administration of Dacryodes edulis fruit oil in UCMS paradigm by investigating chronic stress induced behavioral alterations in mice.

\section{Material and Methods}

\section{Preparation of the essential oil}

The fruits were pitted, and the pulp put to dry room temperature until needed. Fractions of $500 \mathrm{~g}$ dried pulp fruit were submitted to hydro distillation for approximately $3 \mathrm{~h}$. Oil extracting was dried by placing at $37^{\circ} \mathrm{C}$ until needed. The concentrated oil sample was used for experiments, in the dilution of $10 \%$ in distillated water.

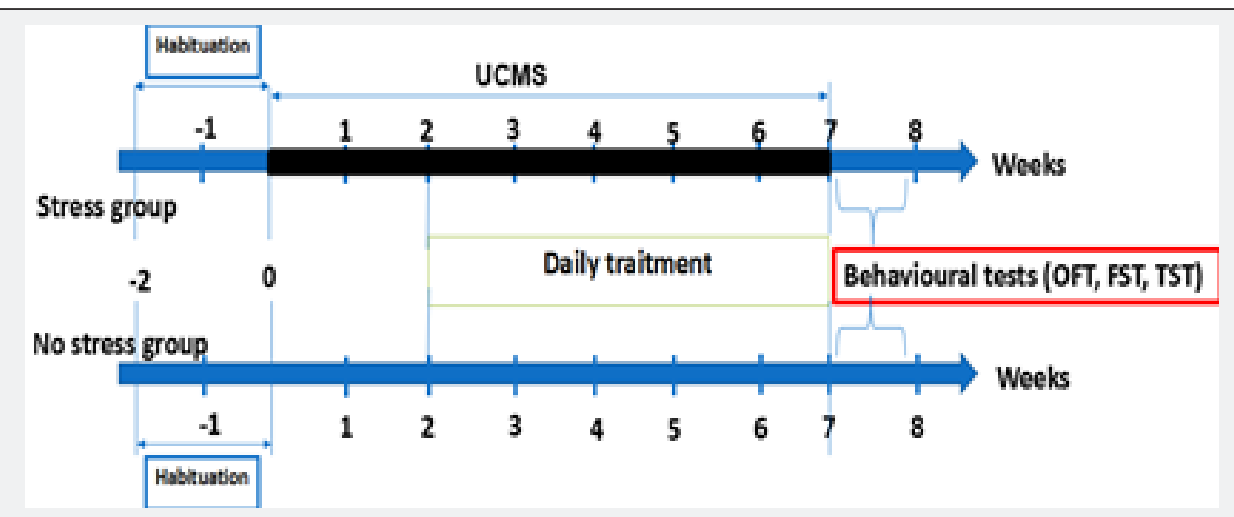

Figure 1: Experimental procedure of unpredictable chronic mild stress (UCMS). OFT: Open field test; FST: forced swimming test; TST: tail suspension test.

\section{Animals}

Adult male mice aged between 6 to 8 weeks, from the animal house of the Faculty of Health Sciences of the Marien Ngouabi University (Brazzaville), were used. They were raised in polypropylene cages, at an ambient temperature of $25^{\circ} \mathrm{C}$ and a light/dark cycle of $12 \mathrm{~h} / 12$, with free access to water and food. All experiments were conducted in compliance with Directive 2010/6106/EU, on the protection of laboratory animals [16]. Animals were divided into 4 lots of 5 mice; distilled water $(5 \mathrm{ml} / \mathrm{kg})$, fluoxetine (FLU) $2,5 \mathrm{mg} / \mathrm{kg}$, D. edulis (HDE) oil, 5 and $10 \mathrm{ml} / \mathrm{kg}$. Positive control and treated groups were subjected to an unpredictable moderate chronic stress (UCMS) protocol, for 6 weeks $[17,18]$. The different products were administered daily orally, at the same time and 2 weeks after the start of the protocol, until the end of it (Figure 1).

\section{Unpredictable chronic mild stress protocol}

Unpredictable chronic mild stress protocol was previously described by Surget [19] and several variants have been proposed [12]. In our protocol, mice were routinely subjected to a variety of socio-environmental stressors, following a pre-established schedule, for a duration of 6 weeks (Table 1). The different stressors were: alteration of the soiled sawdust, clean, wet, change of cage, substitution of the sawdust by water, cage tilt at $45^{\circ}$, inversion of the light/dark cycle, bath.

Table 1: Synopsis of the Unpredictable Moderate Chronic Stress Protocol [18].

\begin{tabular}{|c|c|c|c|c|c|c|c|}
\hline Week & Day 1 & Day 2 & Day 3 & Day 4 & Day 5 & Day 6 & Day 7 \\
\hline 1 & $\begin{array}{c}\text { Social stress } \\
(12 \mathrm{~h} 30-14 \mathrm{~h} 30) \\
\text { Without saw- } \\
\text { dust } \\
(15 \mathrm{~h} 30-18 \mathrm{~h} 30)\end{array}$ & $\begin{array}{c}3 \text { rat soiled sawdust } \\
\text { Changing }(10 \mathrm{~h}-11 \mathrm{~h}) \\
\text { Bath } \\
(15 \mathrm{~h} 00-15 \mathrm{~h} 30)\end{array}$ & $\begin{array}{c}\text { Bath }(10 \mathrm{~h}-11 \mathrm{~h}) \\
\text { Small tubes } \\
(15 \mathrm{~h} 30-16 \mathrm{~h}) \\
\text { Without sawdust } \\
(16 \mathrm{~h}-18 \mathrm{~h})\end{array}$ & $\begin{array}{c}\text { Bath } \\
(9.30-10.30) \\
3 \text { rat soiled saw- } \\
\text { dust } \\
\text { changing } \\
(15 \mathrm{~h}-16 \mathrm{~h})\end{array}$ & $\begin{array}{c}\text { Without } \\
\text { sawdust } \\
(10 \mathrm{~h}-12 \mathrm{~h} 30) \\
\text { Reversal } \\
\text { light/dark } \\
\text { cycle }\end{array}$ & $\begin{array}{l}\text { Short succes- } \\
\text { sion } \\
\text { light / dark } \\
\text { every hour } \\
\text { (10h-14h) }\end{array}$ & $\begin{array}{c}\text { Without } \\
\text { sawdust } \\
(12 \mathrm{~h}-14 \mathrm{~h}) \\
\text { Small tubes } \\
(14 \mathrm{~h}-16 \mathrm{~h}) \\
\text { New sawdust } \\
\text { (18h) }\end{array}$ \\
\hline
\end{tabular}




\section{Psychology and Behavioral Science International Journal}

\begin{tabular}{|c|c|c|c|c|c|c|c|}
\hline 2 & $\begin{array}{l}\text { Cages tilt at } 45^{\circ} \\
(9 \mathrm{~h}-10 \mathrm{~h}) \\
\text { Without saw- } \\
\text { dust }(11 \mathrm{~h}) \\
\text { Bath }(12 \mathrm{~h} 30- \\
13 \mathrm{~h} 30)\end{array}$ & $\begin{array}{c}\text { Damp sawdust } \\
(9.30-11.30) \\
10 \text { sec in water } 20^{\circ} \mathrm{C} \\
(13 \mathrm{~h}) \\
\text { Without sawdust } \\
(15 \mathrm{~h}-16 \mathrm{~h})\end{array}$ & $\begin{array}{c}\text { Reversal of light/ } \\
\text { dark cycle } \\
\text { Social stress } \\
(10 \mathrm{~h}) \\
\text { Rat sawdust } \\
(14 \mathrm{~h}) \\
\text { Social stress } \\
\text { (16h-18h) }\end{array}$ & $\begin{array}{c}\text { Without sawdust } \\
\text { (9h-10h30) } \\
\text { Small tubes } \\
\text { (10h30-11h30) } \\
\text { New sawdust }(14 \mathrm{~h})\end{array}$ & $\begin{array}{l}\text { Short succes- } \\
\text { sion light/ } \\
\text { dark every } 1 \mathrm{~h} \\
(14 \mathrm{~h}-18 \mathrm{~h})\end{array}$ & $\begin{array}{l}\text { Short succes- } \\
\text { sion light/ } \\
\text { dark every } 1 \mathrm{~h} \\
\text { (10h-14h) } \\
\text { Pinching of } \\
\text { the tail } \\
(16 \mathrm{~h})\end{array}$ & $\begin{array}{l}\text { Reversal } \\
\text { light/dark } \\
\text { cycle }\end{array}$ \\
\hline 3 & $\begin{array}{c}\text { Damp sawdust } \\
(10 \mathrm{~h} 30-12 \mathrm{~h} 30) \\
\text { Restricted } \\
(15 \mathrm{~h}-16 \mathrm{~h})\end{array}$ & $\begin{array}{l}\text { Cage tilt } 45^{\circ} \\
(11 \mathrm{~h}-14 \mathrm{~h}) \\
\text { Damp sawdust } \\
(17 \mathrm{~h}-18 \mathrm{~h})\end{array}$ & $\begin{array}{c}\text { Without sawdust } \\
(13 \mathrm{~h}) \\
\text { Social stress } \\
(15 \mathrm{~h})\end{array}$ & $\begin{array}{l}\text { Reversal light/dark } \\
\text { cycle }\end{array}$ & $\begin{array}{c}\text { New sawdust } \\
(10 \mathrm{~h}) \\
\text { Social stress } \\
(15 \mathrm{~h})\end{array}$ & $\begin{array}{c}\text { Short succes- } \\
\text { sion light/dark } \\
\text { every } 1 \mathrm{~h} \\
(9 \mathrm{~h}-18 \mathrm{~h})\end{array}$ & $\begin{array}{c}\text { Bath } \\
(12 \mathrm{~h}-14 \mathrm{~h}) \\
\text { Social stress } \\
(14 \mathrm{~h}) \\
\text { Wet sawdust } \\
(15 \mathrm{~h}) \\
\end{array}$ \\
\hline 4 & $\begin{array}{c}\text { Old rat sawdust } \\
(10 \mathrm{~h} 30) \\
\text { Small tubes } \\
(14 \mathrm{~h}) \\
\text { Wet litter } \\
(15 \mathrm{~h}-17 \mathrm{~h})\end{array}$ & $\begin{array}{c}\text { New sawdust (9h) } \\
\text { Cage tilt } 45^{\circ} \\
(11 \mathrm{~h}-14 \mathrm{~h}) \\
\text { Old rat sawdust } \\
(14 \mathrm{~h})\end{array}$ & $\begin{array}{c}\text { New sawdust (9h) } \\
\text { Bath }(10 \mathrm{~h}-11 \mathrm{~h}) \\
\text { Tail Pinching } \\
(16 \mathrm{~h})\end{array}$ & $\begin{array}{c}\text { Cages Tilt } 45^{\circ} \\
\text { (10h-13) } \\
\text { Tail pinching } \\
(14 \mathrm{~h}-14 \mathrm{~h} 30) \\
\text { Wet litter } \\
\text { (15h-16h30) } \\
\text { Social stress and } \\
\text { new litter (16h) }\end{array}$ & $\begin{array}{l}\text { Short succes- } \\
\text { sion } \\
\text { light / dark } \\
\text { every } 1 \mathrm{~h} \\
\text { (9h-18h) }\end{array}$ & $\begin{array}{l}\text { Reverse } \\
\text { light/dark } \\
\text { cycle }\end{array}$ & $\begin{array}{l}\text { Cages tilt } 45^{\circ} \\
\text { (11h-13) } \\
\text { Without } \\
\text { sawdust } \\
(13 \mathrm{~h}-15 \mathrm{~h}) \\
\text { Social stress } \\
(15 \mathrm{~h})\end{array}$ \\
\hline 5 & $\begin{array}{l}\text { New sawdust } \\
(14 \mathrm{~h}) \\
\text { Old rat sawdust } \\
(16 \mathrm{~h} 30) \\
\text { Social stress } \\
(17 \mathrm{~h} 30)\end{array}$ & $\begin{array}{c}\text { Cage tilt } 45^{\circ}(14 \mathrm{~h}) \\
\text { Social stress }(15 \mathrm{~h}) \\
\text { Small tubes }(15 \mathrm{~h} 30- \\
17 \mathrm{~h} 30)\end{array}$ & $\begin{array}{c}10 \mathrm{sec} \text { in water } \\
20^{\circ} \mathrm{C}(11 \mathrm{~h}) \\
\text { Small tubes } \\
(12 \mathrm{~h} 30) \\
\text { Rat sawdust } \\
(16 \mathrm{~h}-18 \mathrm{~h}) \\
\text { New sawdust } \\
(14 \mathrm{~h} 30-16 \mathrm{~h} 30)\end{array}$ & $\begin{array}{c}\text { New sawdust }(9 \mathrm{~h}) \\
\text { Old rat sawdust } \\
(11: 30) \\
\text { Tail pinching } \\
(16 \mathrm{~h})\end{array}$ & $\begin{array}{c}\text { Social stress } \\
(14 \mathrm{~h}) \\
\text { Wet sawdust } \\
(15 \mathrm{~h}) \\
\text { Social stress } \\
(16 \mathrm{~h}) \\
\text { New sawdust } \\
(16 \mathrm{~h} 30)\end{array}$ & $\begin{array}{l}\text { Reverse light/ } \\
\text { dark } \\
\text { cycle } \\
\text { Tail pinching } \\
\text { (16h) }\end{array}$ & $\begin{array}{l}\text { Short succes- } \\
\text { sion light/ } \\
\text { dark every } 1 \mathrm{~h} \\
(9 \mathrm{~h}-18 \mathrm{~h})\end{array}$ \\
\hline 6 & $\begin{array}{l}\text { Social stress } \\
\quad(14 \mathrm{~h}) \\
\text { Cage tilt } 45^{\circ} \\
(14 \mathrm{~h} 30-17 \mathrm{~h} 30)\end{array}$ & $\begin{array}{c}\text { Cage tilt } 45^{\circ}(10 \mathrm{~h}) \\
\text { Without sawdust } \\
\qquad(15 \mathrm{~h})\end{array}$ & $\begin{array}{l}\text { New sawdust (9h) } \\
\text { Strong light } \\
(8 \mathrm{~h}-12 \mathrm{~h})\end{array}$ & $\begin{array}{l}\text { Reverse light/dark } \\
\text { cycle }\end{array}$ & $\begin{array}{l}\text { Social stress } \\
\text { (14h) } \\
\text { Tilt cage } \\
45(14 \mathrm{~h})\end{array}$ & $\begin{array}{c}\text { Short succes- } \\
\text { sion } \\
\text { light/dark } \\
\text { every } 1 \mathrm{~h} \\
\text { (9h-18h) } \\
\end{array}$ & $\begin{array}{l}\text { Cage tilt } 45^{\circ} \\
(14 \mathrm{~h}-16 \mathrm{~h}) \\
\text { Small tubes } \\
(17 \mathrm{~h}-18 \mathrm{~h})\end{array}$ \\
\hline
\end{tabular}

The different products were administered orally daily, during 4 weeks, 14 days following the start of the protocol. 24 hours after the cessation of the stress protocol, all the animals were subjected to the open field test, forced swimming test $(J+2$ post protocol) and tail suspension test $(\mathrm{J}+3$ post protocol).

\section{Body weight and coat state}

Body weight and coat state were assessed weekly as predictors of unpredictable chronic moderate stress and protocol validity, consistent with the protocol reported by Laugeray et al. [18]. The evaluation of the coast state was carried out by assessment of 8 different body parts: head, neck, dorsal coat, ventral coat, tail, forepaws, hind paws and genital region [20]. A score of 0 was attributed to a smooth coat, in good state. Dirty state was characterized by a flu fly, greasy, less dense coat or piloerection, and attributed to a score of 1 for a coat. Sum of score obtained with each of these different parts gave us an index of general physical state of an animal.

\section{Forced swimming test}

The principle of forced swimming test (FST) lies in its supposed relationship with resignation behavior. It is a behavioral test mainly used to predict the effectiveness of antidepressant treatment $[20,21]$. It involves subjecting the animals to forced swimming for 6 minutes. After vigorous activity for two minutes, the animal stops swimming and freezes, adopting a behavior of resignation that can be associated with "despair". It is considered that the mouse is immobile when it floats in a horizontal position and makes only movements of small amplitude allowing him to keep his head out of the water.

The mice were placed in a cylinder $(19 \mathrm{~cm}$ diameter, $23 \mathrm{~cm}$ deep), filled to two-thirds with $23-25^{\circ} \mathrm{C}$ water and the latency (time that the animal puts before the immobilization) of the first immobilization as well as the total duration of immobility or floating are recorded. Only the last 4 min were scored for mobility duration. Immediately after the test, the mouse is placed in a heating chamber for 10 minutes to promote its recovery.

\section{Caudal suspension test}

The tail suspension test (TST) is used to evaluate the antidepressant properties of a substance. It is based on the fact that an animal suspended by the tail presents alternating periods of agitation and immobility. The duration of immobility is considered as an index of resignation. Mice were suspended in the air using a paper clip fixed by tape wrapped around their tails about $20 \mathrm{~mm}$ from the extremity of the tail. The duration of immobility was recorded during the last $4 \mathrm{~min}$ of the $6 \mathrm{~min}$ test $[6,22,23]$. Antidepressants reduce the total duration of this immobility.

\section{Statistical analysis}

The results were analyzed with the InStat 3.036 software and averaged \pm standard error. We used the test $t$ of Student with a significance level set at $p<0.05$. 


\section{Psychology and Behavioral Science International Journal}

\section{Results}

Figures 2 and 3 show respectively the weight change and the state of the coat of animals subjected to chronic stress. The stress model used significantly inhibits weight gain from the six weeks of the protocol (Figure 2). We also observed a deterioration in the coat state which is observed at the first week of the protocol to the sixth (Figures $3 \& 4$ ), resulting in a significant increase in the score attributed to the state of the coat: $p<0.001$. Figure 4 illustrates the coat state of the animal submitted (a) or not (b) to the UCMS protocol.

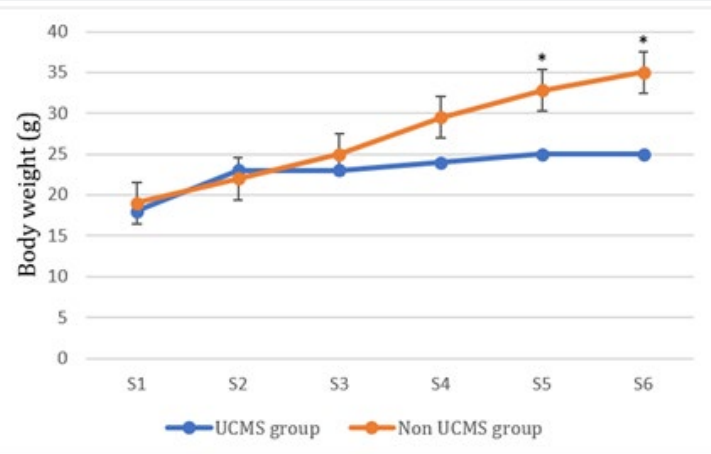

Figure 2: Effects of moderate, unpredictable chronic stress on animal weight. The results are expressed as mean \pm standard error. *: $p$ $<0.05$ by the $t$ student test $(n=5)$. UCMS Group: group of stressed animals; Non UCMS group: group of animals not stressed; S: week.

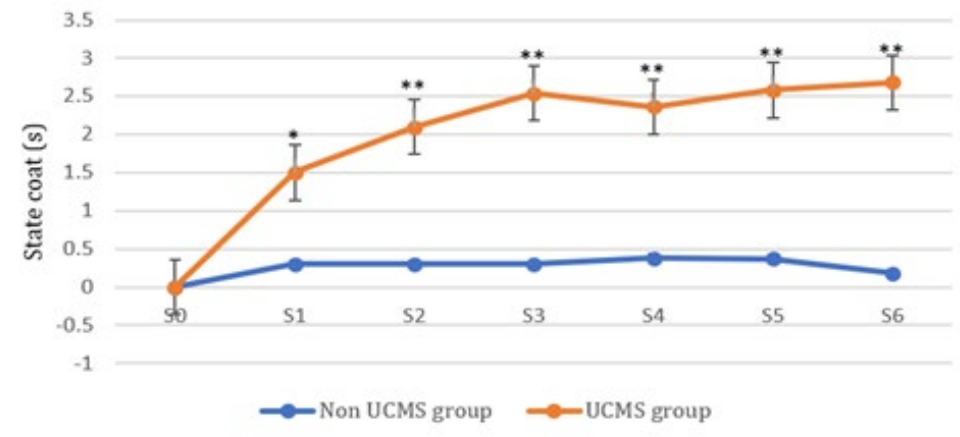

Figure 3: Effects of unpredictable moderate chronic stress on the condition of the animal's coat. A score, expressed as mean \pm standard error, reflects the state of the fur of animals subjected or not to stress. ${ }^{*}: p<0.05 ;{ }^{* *}: p<0.001$ by the $t$ student test $(n=5)$. UCMS Group: group of stressed animals; Non UCMS group: group of unstressed animals; S: week.
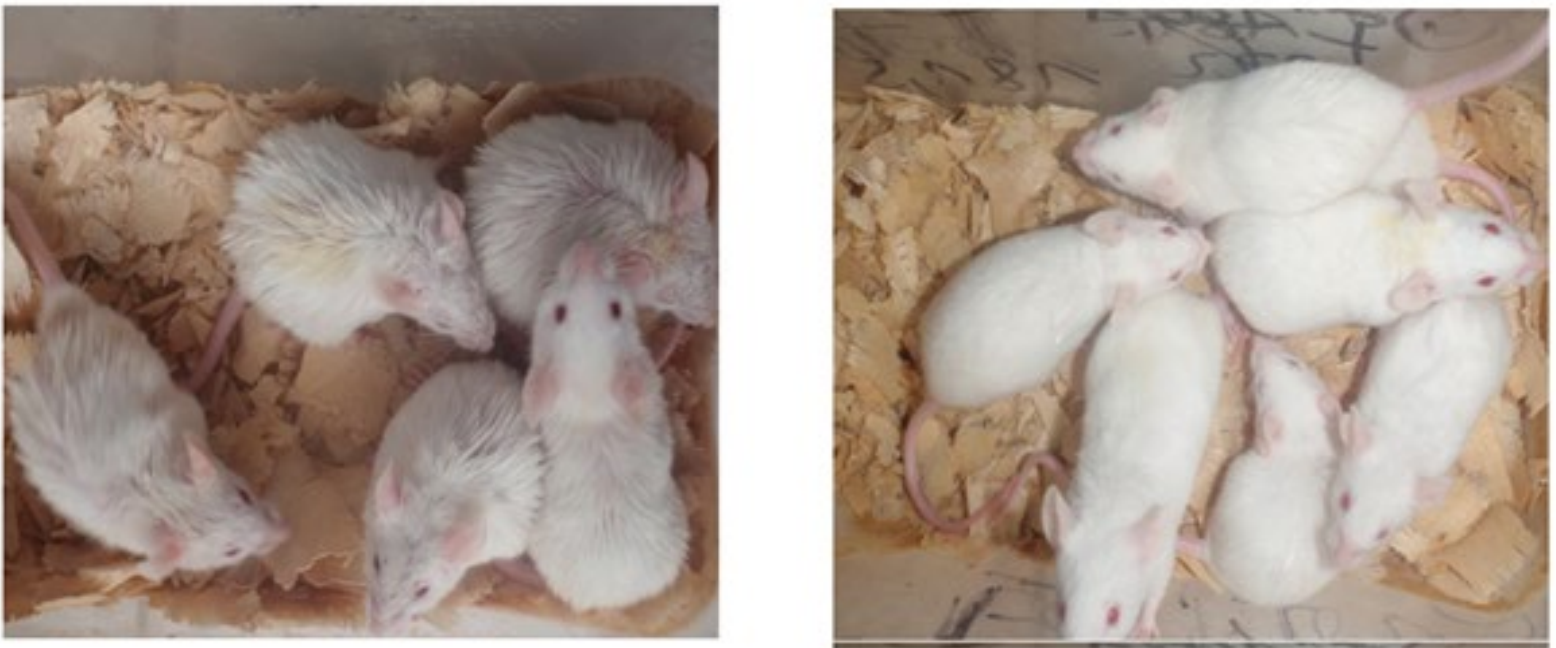

Figure 4: Photography of animals coat state. (a). stressed group (UCMS), degraded coat; (b). unstressed group (non UCMS), neat coat. 


\section{Psychology and Behavioral Science International Journal}

\section{Effects of HDE on the coat state of animals}

Figure 5 shows the effects of the treatments on the animal coat state. The results show that the degradation of the coat state is corrected from the 4 th week of treatment. This correction is significant $(\mathrm{p}<0.001)$ at the $5^{\text {th }}$ and $6^{\text {th }}$ week.

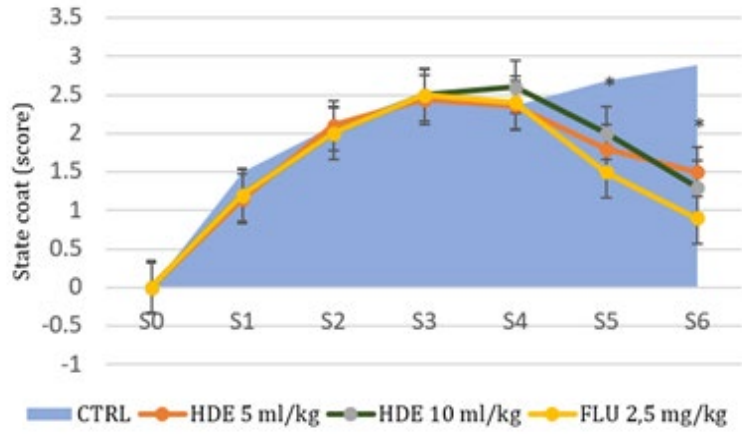

Figure 5: Effects of treatments on the state coat of animal in UCMS protocol. A score, expressed as mean \pm standard error, reflects the coat state of the animals subjected or not to stress. ${ }^{*}: p<0.05$ by the t student test $(n=5)$. CTRL: control; S: week; HDE: D. edulis oil; FLU: fluoxetine.

\section{Forced swimming test (FST)}

D. edulis and fluoxetine increase the latency of animals and significantly reduce $(p<0.01)$ the duration of immobility in the forced swimming test (Figures $6 \& 7$ ).

\section{Caudal suspension test}

D. edulis and fluoxetine increase the latency of animals in the tail suspension test and significantly reduce $(\mathrm{p}<0.01)$ the duration of immobility (Figures 8 \& 9).

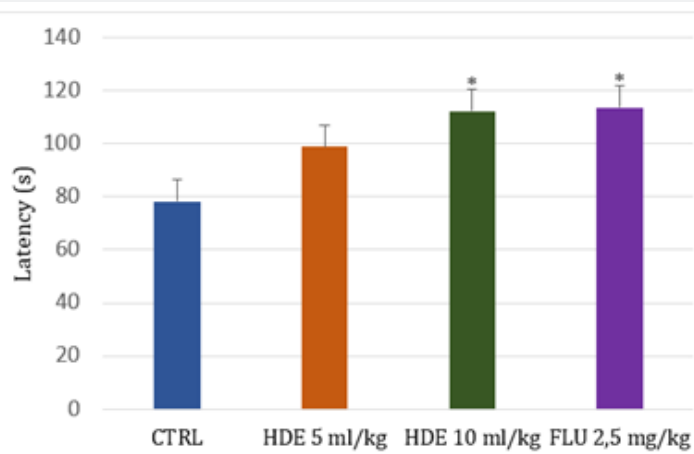

Figure 6: Effects of treatment on the latency of animals under stress, in the forced swimming test (FST). The results are expressed as mean \pm standard error. ${ }^{*}: p<0.05$ by the t student test $(n=5)$. CTRL: control; HDE: oil of $D$. edulis; FLU: fluoxetine.

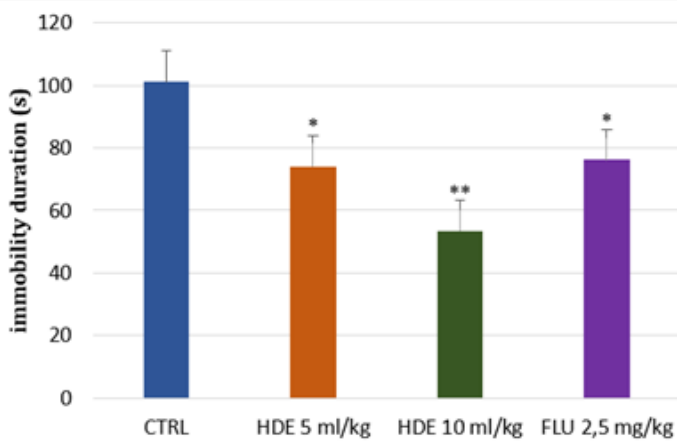

Figure 7: Effects of treatments on the immobility duration of animals under stress, in the forced swimming test (FST). The results are expressed as mean \pm standard error. ${ }^{*}: p<0.05 ;{ }^{* *}: p<0.001$ by the $t$ student test $(n=5)$. CTRL: control; HDE: oil of $D$. edulis; FLU: fluoxetine. 


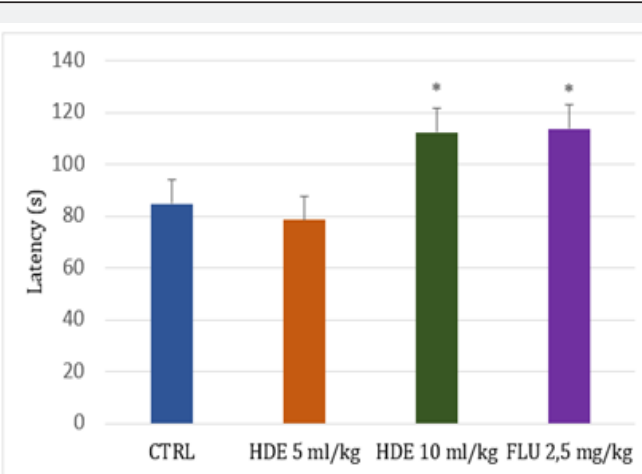

Figure 8: Effects of treatment on the latency of animals under stress, in the tail suspension test (TST). The results are expressed as mean \pm standard error. *: $p<0.05$ by the t student test $(n=5)$. CTRL: control; HDE: oil of D. edulis; FLU: fluoxetine.

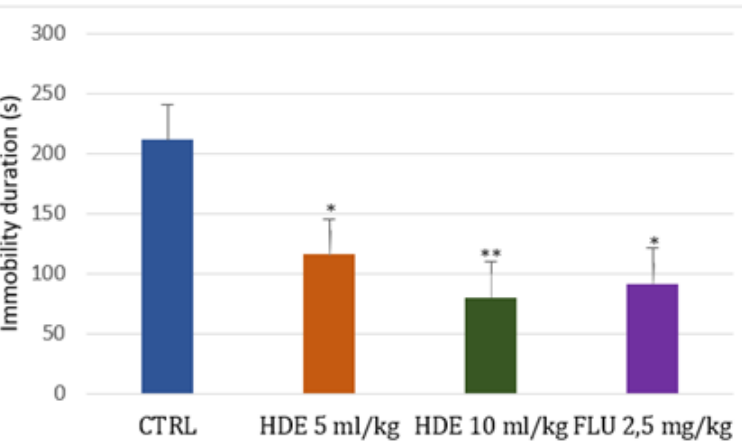

Figure 9: Effects of treatments on the immobility duration of animals under stress, in the tail suspension test (TST). The results are expressed as mean \pm standard error. ${ }^{*}: p<0.05 ;{ }^{* *}: p<0.001$ by the t student test $(n=5)$. CTRL: control; HDE: oil of D. edulis; FLU: fluoxetine.

\section{Discussion}

Many studies report that a complex relationship is there among stressful situations, mind and body's reaction to stress, and the onset of clinical depression [3]. Some stress-provoked disorders seem to be associated with the pathophysiology of depression [24]. Depression and stress are associated with functional and morphological changes in the nervous system [25]. The chronic administration of various uncontrollable stressors in an unpredictable manner is a well-documented animal model for the preclinical evaluation of antidepressants $[26,27,28]$. Unpredictable Chronic Mild Stress (UCMS) induces a complex syndrome, similar to the symptoms of major depression observed in human pathology. As a result, this model has a very good descriptive validity [3].

In this study, we used the unpredictable mild chronic stress model to evaluate the effects of long-term administration of $D$. edulis oil on stress-induced symptoms of depression. The mice were exposed to a series of physical and psychosocial stress. The behavioral parameters analyzed in our experiments were the coat state, latency and the duration of immobility in the FST and the TST.

In mice, grooming is a behavior that is very sensitive to stress $[29,30]$. In UCMS model, the deterioration of the coat state ob- served is related to the decrease in the grooming behavior, consequence of the neurobiological changes caused by the prolonged exposure to the different stressors [31]. In clinic, the equivalent of this symptomatology is the lack of hygiene observed to some depressant patients. The results obtained showed a significant degradation of the state of the fur of the animals subjected to the UCMS. In fact, the deterioration of the coat as a result of chronic stress has been observed in many studies [18,32]. In the present study, degradation of the state coat, bio-behavioral marker, settles in the first week of stress and continues throughout the duration of the protocol. Degradation of the coat state, associated with loss of body weight gain, is a characteristic that reflects depression [31], and validates the stress protocol. This observation is consistent with the literature data $[19,31,33]$. The importance of losing weight gain depends on the duration, timing and type of stressors used [31]. In our study, the loss of weight gain with UCMS group was significant from the 5 th week of the stress protocol.

Increased animal immobility in the FST and TST is considered a marker of anxiety behavior [21,34]. Mice that were exposed to a regime of chronic stress exhibited greater immobility period as compared to control animals. The increase in immobility time was significantly reversed by daily administration of HDE. UCMS has been shown to cause decreased immobility in the FST and TST in animals. These observations corroborate with the interpreta- 
tion of this behavior conventionally carried out in this paradigm $[6,35]$. Our results indicate that HDE increases latency and decreases immobility in the FST and TST. In these tests, it is estimated that the latency of animals before immobility is linked to an attitude of resignation / loss of motivation to get out of a dead-end situation, which we often see appearing in the literature under the term "Behavioral despair". It has been shown that various antidepressants decrease the duration of immobility in mice [21], interpreted as an increase in motivation / combativeness in a situation that cannot be extracted. These arguments justify that chronic stress, supposed to induce a depressive state, causes an increase in the duration of immobility. However, other experimental studies have reported a decrease in immobility in the FST after chronic stress [36-38]. This diversity of observations could be attributed to methodological divergences such as water temperature or light intensity [39-41].

Despite these differences in behavioral interpretation, the relevance of this model has been reported in several studies. Indeed, it is the best model to study the pathophysiology of depressive disorders because it uses one of the main etiological factors of depression: chronic exposure to stressors, giving it a good build validity. Previous studies have shown that HDE opposes symptoms of depression and anxiety in behavioral tests after acute administration in rodent $[14,15]$. In this study, chronic administration of HDE restored stress-induced behavioral changes in UCMS protocol, probably by preventing oxidative stress and inflammation in mice hippocampal neurons and consequently may be improving synaptic plasticity. Subsequent studies would elucidate the neurobiological mechanisms of HDE effects in stress-induced behavioral and biochemical changes.

\section{Conclusion}

D. edulis oil administered to animals daily for 30 days, showed the antidepressant-like effect in unpredictable chronic mild stress-induced depression model in mice, by improving the symptoms of depression in the behavioral tests of forced swimming and tail suspension test. Subsequent studies would elucidate the neurobiological mechanisms of these effects of HDE.

\section{Acknowledgment}

The authors would like to express their gratitude to the Biochemistry and Pharmacology Laboratory, and its head, Professor Ange Antoine ABENA, for the provided experimental material.

\section{Conflict of Interest}

Authors declare there is no conflict of interest.

\section{References}

1. Jacobson l, Sapolsky R (1991) The role of the hippocampus in feedback regulation of the hypothalamo- pituitary- adrenocortical axis. Endocr Rev 12: 118-134.
2. Sherki YG, Melemed E, Offen D (2001) Oxidative stress induced neuro degenerative diseases: the need for antioxidants that penetrate the blood brain barrier. Neuropharmacology 40: 959-975.

3. Kumar Anil, Garg Ruchika and Prakash Atish KR (2010) Effects of St. John $>$ S Wort (Hypericum perforatum) treatment on restraint stress-induced behavioral and biochemical alteration in mice. BMC Complement Altern Med 18: 1-6.

4. Strauman TJ, Vieth AZ, Merrill KA, Kolden GG, Woods TE, et al. (2006) Self-system therapy as an intervention for self-regulatory dysfunction in depression: a randomized comparison with cognitive therapy. J Consult Clin Psychol 74: 367-376.

5. Moussavi S, Chatterji S, Verdes E, Tandon A, Patel V, et al. (2007) Depression, chronic diseases, and decrements in health: results from the World Health Surveys. Lancet 370: 851-858.

6. Zhu S, Shi R, Wang R, Wang JF, Li XM (2014) Unpredictable chronic mild stress depression stress induces depressive behaviors in mice. Neuroreport 25 (14): 1151-55.

7. Berton 0, Nestler EJ (2006) New approaches to antidepressant drug discovery: beyond monoamines. Nat Rev Neurosci 7: 137-151.

8. Nemeroff CB (2007) The burden of severe depression: a review of diagnosis and treatment. J Psychiatr Res 41: 189-206.

9. Nestler EJ, Barrot M, DiLeone RJ, Eisch AJ, Gold SJ, et al. (2002) Neurobiology of depression. Neuron 34: 13-25.

10. Cryan JF, Markou A, Lucki I (2002) Assessing antidepressant activity in rodents: recent developments and future needs. Trends Pharmacol Sci 23: 238-245.

11. Willner P, Towell A, Sampson D, Sophokleous S, Muscat R (1987) Reduction of sucrose preference by chronic unpredictable mild stress, and its restoration by a tricyclic antidepressant. Psychopharmacology 93: 358-364.

12. Willner P (1997) Validity Reliability and Utility of the Chronic Mild Stress Model of Depression: a 10-year review and evaluation. Psychopharmacology (Berl) 134: 319-329.

13. Bilici M, Efe H, Koroglu MA, Uydu HA, Bekaroglu M, et al. (2001) Antioxidative enzyme activities and lipid peroxidation in major depression: alterations by antidepressant treatments. J Affect Disord 64: $43-51$

14. Miguel LM, Mouankie JB, Okemy N, Mokondjimobe E and al. (2014) Psychopharmacological effects of the essential oil of Dacryodes edulis fruits (G. Don) HJ Lam. Ann Univ M. NGOUABI 15 (5): 61-72.

15. Miguel LM, Okemy-Andissa N, N'jilo D, Mokondjimobe E, Moukassa D, et al. (2019) Effects of the fruit oil of Dacryodes edulis on the symptoms of anxiety and cognitive performance in mice, after prolonged administration. Encephale S0013-7006(19): 30183-30186.

16. Hartung $T$ (2010) Comparative analysis of the revised Directive $2010 / 6106 / \mathrm{EU}$ for the protection of laboratory animals with its predecessor 86/609 / EEEEC - t4 report. ALTEX - Alternatives to animal experimentation 27(4): 285-303.

17. Mehta AK, Binkley B, SS Gandhi, Ticku MK (1991) Pharmacodynamic effects of Withania somnifera root extract on GABA A receptor complex. Indian J Med Res 94: 312-315.

18. Laugeray Anthony (2010) Study of the role of the kynurenine pathway in an animal model of depression: unpredictable chronic stress. Th Sc François - Rabelais University of Tours, France p. 329.

19. Surget A, Wang Y, Leman S, Ibarguen-Vargas Y, Edgar N, et al. (2009) Coticolimbic transcriptome changes are state-dependent and regionspecific in a rodent model of depression and reversal antidepressant. 
Neuropsychopharmacology 34: 1363-1380.

20. Ducottet C, Griebel G, Belzung C (2003) Effects of the selective nonpeptide corticotropin-releasing factor receptor 1 antagonist antalarmin in the chronic mild stress model of depression in mice. Prog Neuropsychopharmacol Biol Psychiatry 27: 625-631.

21. Porsolt RD, Bertin A, Jalfre M (1977) Behavioral despair in mice: a primary screening test for antidepressants. Arch Int Pharmacodyn Ther 229: 327-336.

22. Steru L, Chermat R, Thierry B, Simon P (1985) The tail suspension test: a new method for screening antidepressants in mice. Psychopharmacology (Berl) 85 (3): 367-70.

23. Steru L, Chermat R, Thierry B, Mico JA, Lenegre A, et al. (1987) The Automated Tail Suspension Test: a computerized device which differentiates psychotropic drugs. Prog Neuropsychopharmacol Biol Psychiatry 11 (6): 659-671.

24. Kioukia-Fougia N, Antoniou K, Bekris S, Liapi C, Christofidis, et al. (2002) The effects of stress exposure on the hypothalamic-pituitaryadrenal axis, thymus, thyroid hormones and glucose levels. Prog Neuropsychopharmacol Biol Psychiatry 26: 823-830.

25. Brown TA, Chorpita BF, Barlow DH (1998) Structural relation-ships among dimensions of the DSM-IV anxiety and mood disorders and dimensions of negative affect, positive affect, and autonomic arousal. J Abnormal Psychol 107: 179-192.

26. Katz RJ, Schmaltz K (1980) Dopaminergic involvement in attention. A novel animal model. Prog Neuropsychopharmacol Biol Psychiatry 4: 585-590.

27. Willner P (1991) Animal models as simulations of depression. Trends Pharmacol Sci 12: 131-136.

28. Willner P, Muscat R, Papp M (1992) Chronic mild stress-induced anhedonia: a realistic animal model of depression. Neurosci Biobehav Rev 16: 525-534

29. Kalueff AV, Tuohimaa P (2004a) Contrasting grooming phenotypes in C57Bl / 6 and 129S1 / SvImJ mice. Brain Res 1028: 75-82.
30. Kalueff AV, Tuohimaa P (2004b) Grooming analysis algorithm for neurobehavioural stress research. Brain Res Brain Res Protocols 13: 151158.

31. Nollet M, Guisquet AM, Belzung C (2013) Models of Depression: Unpredictable Chronic Mild Stress in Mice. Curr Protoc Pharmacol 5 (65): 1-17.

32. Mutlu O, Ulak G, Laugeray A, Belzung C (2009) Effects of neuronal and inducible NOS inhibitor 1-[2-(trifluoromethyl) phenyl] imidazole (TRIM) in unpredictable chronic mild stress procedure in mice. Pharmacol Biochem Behav 92(1): 82-87.

33. Ibarguen-Vargas Y, Surget A, Touma C, Palme R, Belzung C (2008) Multifaceted strain specific effects in a mouse model of depression and of antidepressant reversal. Psychoneuroendocrinology 33: 1357-1368.

34. Yan B, He J, Xu H, Zhang Y, Bi X, et al. (2007) Quetiapine attenuates the depressive and anxiolytic-like behavioral changes induced by global cerebral ischemia in mice. Behav Brain Res 182: 36-41.

35. Parihar VK, Hattiangady B, Kuruba R, Shuai B, Shetty AK (2011) Predictable chronic mild mood improves mood, hippocampal neurogenesis and memory. Mol Psychiatry 16: 171-183.

36. Hata T, Nishikawa H, Itoh E, Watanabe A (1999) Depressive state with anxiety in repeated cold-stressed mice in forced swimming tests. Jpn J Pharmacol 79 (2): 243-249.

37. Hata T, Nishikawa H, Itoh E, Funakami Y (2001) Anxiety-like behavior in elevated plus-maze tests in repeatedly cold-stressed mice. Jpn J Pharmacol 85 (2): 189-196.

38. Nishikawa H, Hata T, Itoh E (2004) A role for corticotropin-releasing factor in cold stress-induced stress-induced behavior during forced swimming and elevated plus-maze tests in mice. Biol Pharm Bull 27(3): 352-356.

39. Petit-Demouliere B, Chenu F, Bourin B (2005) Forced swimming test in mice: a review of antidepressant activity. Psychopharmacology (Berl) 177 (3): 245-255.

40. Strekalova T, Spanagel R Dolgov O, Bartsch D (2005) Stress-induced hyperlocomotion as a confounding factor in depression and depression

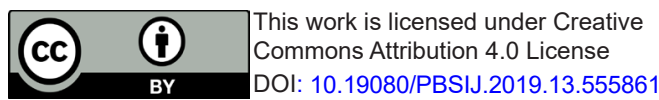

\section{Your next submission with Juniper Publishers will reach you the below assets}

- Quality Editorial service

- Swift Peer Review

- Reprints availability

- E-prints Service

- Manuscript Podcast for convenient understanding

- Global attainment for your research

- Manuscript accessibility in different formats

( Pdf, E-pub, Full Text, Audio)

- Unceasing customer service

Track the below URL for one-step submission https://juniperpublishers.com/online-submission.php 